E Q U I L I B R I U M

Volume 6 IsSue 4, 2011

IS S N $1689-765 \mathrm{X}$

Krzysztof Krukowski

University of Warmia and Mazury, Poland

\title{
Public Organizations in the Context \\ of Corporate Social Responsibility
}

JEL Classification Codes: $M 14$

Keywords: public organization, corporate social responsibility

\begin{abstract}
The debate on corporate responsibility is permeating increasingly to the public sector. The aim of the present work is to discuss possible implications of CSR concepts that could be observed in public organizations. It follows from the research conducted that public organizations are familiarized with the principles of corporate social responsibility and in the majority of cases possess accepted standards of applying them.
\end{abstract}

\section{Introduction}

Corporate social responsibility (CSR) is one of the areas that manifest themselves within the purposes of managing business organizations. According to $\mathrm{M}$. Friedman, while realizing their missions companies should utilize their resources and undertake business activity with a view to increasing their profits as long as this activity remains in accordance with the principles. In other words, what they ought to do is to get involved in open and free competition without applying any tricky or fraudulent solutions (Friedman 1997, p. 59). Such understanding of the concept of corporate social responsibility does not correspond to the concept of CSR included in the Green Paper of the European Commission ${ }^{1}$. This document defines corporate social responsibility with the assumption that companies are free to incorporate social and ecological aspects into their commercial activity and into their contacts with stakeholders. The difference between the two ap-

\footnotetext{
${ }^{1} \mathrm{http}$ ://europa.eu/documentation/official-docs/green-papers/index pl.htm, from 13.02.2011.
} 
proaches consists in answering the question on whether companies undertake socially responsible tasks on principle, or only when undertaking a task can bring some financial benefits. R.W. Griffin (2008) made a statement that corporate social responsibility constitutes an organization's peculiar obligation to protect and strengthen the society in which it exists (p. 143). This thesis presents best the essence of CSR in business organizations. The debate over this issue is more and more frequently transferred into public organizations, e.g., the przejrzysta gmina (transparent commune) programme, or the ethical code of employees of self-governments. A public organization can be roughly defined as a subject that realizes some public interest. These organizations are characterized, among other things, by the following: they were established by legal persons, the purpose of their activities is some public interest and their internal purposes are subjected to the realization of the major purpose (more on the subject in Kożuch 2005, pp. 31-44). The situation appears to be quite clear for such entities; it is not enough for them to declare being socially responsible: they have to act so. It may seem that the public organization, due to its characteristics, is by definition socially responsible. Therefore, we may formulate a thesis that all activities of public organisations, no matter what their character and scope are, should be socially responsible. On the basis of various models of public management, social responsibility in public organizations can be defined as a multidimensional activity that considers the law, national values, political norms, professional standards and the interest of citizens. The grounds for the definition emerge from the concept of the Nowa Stużba Publiczna (the New Public Service) (Kożuch 2004, p.79). The assumption of this concept is that a public organization ought to be characterized by its transparency and orientation towards social participation as well as by openness to new values and democracy.

The present paper attempts to discuss possible applications of the concept of corporate social responsibility in public organizations.

\section{Pyramid of social responsibility in public organizations}

According to A.B. Carroll (1994), in a theoretical dimension corporate social responsibility may be approached as a responsibility that comprises four basic areas: economic, legal, ethical and philanthropic (table 1) (pp. 5-25).

In the case of business they create a specific pyramid and its base is formed by economic responsibility and its peak means philanthropy. If we analyse the above model from the point of view of the public organization then we can say that the pyramid is upside-down, philanthropy (citizenship) is the base, that means public interest, and the peak is creating values and reaching profits (figure 1). 
Table 1. Differences in the perception of the concept of responsibility in public and business organizations

\begin{tabular}{|c|c|c|}
\hline Type of responsibility & Business organization & Public organization \\
\hline Citizenship $^{*}$ & Demanded by society & Required by society \\
\hline Ethical & Expected by society & Required by society \\
\hline Legal & Required by society & Required by society \\
\hline Economic & Required by society & Demanded by society \\
\hline
\end{tabular}

* In business it is also referred to as philanthropy

Source: elaborated by the author based on A. B. Carroll's model.

Figure 1. Pyramid of social responsibility in the public organization

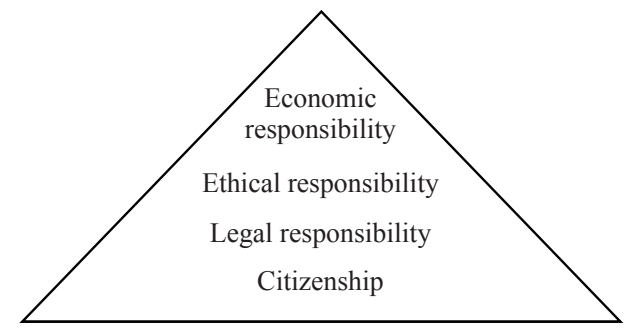

Source: elaborated by the author based on A. B. Carroll's concept.

Citizenship comprises any pro-social activity and is located at the bottom of the CSR pyramid created for the public organization. A major characteristic of the public organization is its public. This characteristic manifests itself in four dimensions: relationships with the environment, distinguishable objectives, structure and values (Kożuch 2005, p. 35). Public organizations have to frequently perform services to people who cannot afford to pay for them. This results from the fact that these organizations are not allowed to exclude any citizen from access to the consumption of the goods that they produce (Zalewski 2005, p. 11). Even in the situation when it is possible to realize such exclusion, relatively high costs are incurred. To illustrate this, we may consider the national defence system in Poland that, in fact, concerns all Polish citizens. The organization that has to render services in this case is the Ministry of National Defence and they have to do it whether they like it or not. The situation discussed concerns primarily public goods, in the narrower sense, it concerns public services.

They are financed by public funds exclusively. However, nowadays, public goods that fall into the largo category, where private entities partially finance some service, become more frequent. In such cases the concept of citizenship 
diminishes. Let us consider the construction of motorways, or the National Health System. In the case of the National Health System situations in which the state is not able to provide some medical services to all citizens that need them is becoming more common. So, can we risk a statement that despite the fact that public organizations have mandatory social responsibilities they do not fulfil the basic assumption resulting from the presented model?

The second level in the pyramid created for the public organization is legal liability, that is meeting the binding regulations while performing the mandatory duties. The public organization itself quite frequently functions as a regulatory body and the examples of such bodies include the local self-government, the Seym, the government with its ministries. According to M. Webber's administrational approach, the activity of the aforementioned entities is based on the procedures devised in accordance with the recorded legal regulations. Therefore, it is an 'acceptable' situation for public organizations when they follow binding regulations and fulfil the second postulate of being socially responsible. However, everyday practice shows clearly that it is not so. We hear about various cases of breaching the law by different public organizations, or about cases when these organizations, in order to realize their statutory goals, undertake an action that is on the edge of the law.

W. Kieżun (2005) identified a few causes related to some pathologies in managing that affect the current state of affairs (pp. 31-44). He tied that with the deficit of social capital in public organizations. The existing pathologies of management can manifest themselves in:

- spreading moral indifference that stimulates various forms of corruption and nepotism;

- treating the private interest or the interest of a political party, some group, etc. as more important than the interest of all citizens;

- egoistic attitudes characterized by greed and the desire to become affluent;

- insufficient trustworthiness in the understanding of praxeology ${ }^{2}$.

The concept of trustworthiness is connected with the third sphere of social responsibility, that is consistency with ethical values shared by society. Ethics as a discipline and part of philosophy concerns values. Ethics started to be treated as a separate area of knowledge as early as in ancient times. At present the area of focus in this discipline is business ethics. The features that differentiate ethics from social responsibility include the period of the interest, area of knowledge, entities and a possibility of managing (table 2).

${ }^{2}$ Tadeusz Kotarbiński described a trustworthy caretaker as a person who shows a kind and friendly attitude to persons in his care, 'sensitive to other people's needs and willing to help' (Kotarbiński 1987, p. 378). 
It is easier to define the ethical code in the context of the public organization than in the context of commercial entities. Businesses use the concept of business ethics. As regards ethics there are no values that would be shared by the whole organization but only by its individual employees, hence the creation of certain ethical codes, such as, for instance, codes regulating the conduct of clerks. In Poland there are some actions conducted in order to broaden and specify the issues included in the ethics of public administration such as, e.g., the 'przejrzysta gmina' (transparent commune) programme. The aforementioned term of trustworthiness illustrates well the values that should be displayed by public organizations. These include the following ones: honesty, conscientiousness, loyalty, punctuality, preciseness and a systematic approach.

Table 2. Differences between ethics and social responsibility in public organizations

\begin{tabular}{|c|c|c|}
\hline Features & Ethics & Social responsibility \\
\hline Period of the interest & $\begin{array}{c}\text { As a separate area of } \\
\text { philosophy already known in } \\
\text { ancient times }\end{array}$ & $\begin{array}{c}\text { Basic terminology comes } \\
\text { from the mid-twentieth } \\
\text { century }\end{array}$ \\
\hline Area of knowledge & A separate area of philosophy & $\begin{array}{c}\text { More pragmatism - paying } \\
\text { attention to practical aspects } \\
\text { of an organization's activity }\end{array}$ \\
\hline Entity & Individual employees & $\begin{array}{c}\text { Organization perceived as an } \\
\text { entity }\end{array}$ \\
\hline $\begin{array}{c}\text { Possibility of managing } \\
\text { (leading) }\end{array}$ & $\begin{array}{c}\text { It is impossible to manage } \\
\text { (lead) ethics }\end{array}$ & $\begin{array}{c}\text { It is possible to manage } \\
\text { social responsibility in an } \\
\text { organization }\end{array}$ \\
\hline
\end{tabular}

Source: elaborated by the author based on Walkowiak, Oliński 2009, p. 34.

The last aspect of the considered concept concerns the economic area. In the case of the public organization this aspect seems to be of a lesser importance, opposite to commercial organizations. Public entities by their definition perform a non-profit activity; however, we must take into account the fact that they charge some fees for the performance of their services, such as, for example, fees for issuing driving licences or city transport fares. This is connected with establishing the price level for performed services. In their activities public organizations focus on the purposefulness and efficiency of these activities and avoid focusing on the concept of effectiveness. With such assumptions in place, it should not be expected that services rendered by these organizations would have market prices. An attempt to apply the market mechanism to the sector of public services was made in Great Britain by M. Thatcher and the aftermath was limiting access to public services for some British citizens. This change led to the situation in which public entities need to take over the performance of services from private 
entities. This results from the fact that it cannot be expected that a private entity should perform a service below costs, even if these services concern the area of public utility. The example to illustrate this point is the city transport system, which has to maintain even those lines that are not profitable. Consequently, it may be stated that social responsibility in public organizations in the economic area primarily consists in offering services in the areas that the private sector is not interested in.

\section{Research on social responsibility in public organizations}

Below there are some research results concerning social responsibility in public organizations. This research was conducted in 2010 on a sample of 28 entities, out of which 23 represented territorial self-governments, 5 were commercial entities performing public services. The research method applied was a questionnaire distributed for completion by managers. The research in question was done within the project titled: 'CSR in the Region of Warmia and the Mazurian Lake District'. The concept of CSR was known to only $14.3 \%$ of the surveyed subjects and the majority (60.7\% of indications) was familiarized with the subject of social responsibility only partially (figure 1 ).

Figure 1. Knowledge of the concept of corporate social responsibility in organizations (\% of indications)

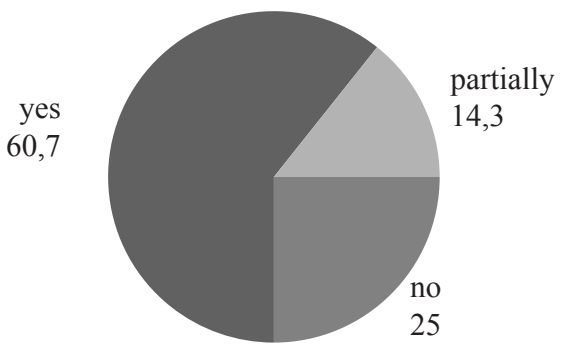

Source: own calculations based on the research results.

The partial understanding of the CSR concept can be proved by the fact that in the opinion of $85.7 \%$ of persons from the researched entities some standards of ethical conduct are in place, which means that one of the elements of ethical responsibility is met. A similar rate of indications occurred in the case of the socially responsible activity. The majority of these indications $(85.7 \%)$ were positive. Only 7.1 of those surveyed were of the opinion that organizations are not 
socially responsible in their activities. Due to the fact that the surveyed research sample included self-governmental units it can be assumed that these respondents meant the ethical code of self-governmental employees. This code constitutes a document describing the values that self-governmental administration is expected to follow. However, the group that said that they were not familiarized with the CSR concept indicated that their organizations possessed standards of ethical conduct. In almost a half of the surveyed entities ethical conduct standards had the form of a written document and $14.3 \%$ of the organizations could boast of their own codes of ethical conduct (figure 2).

Figure 2. Forms of possessed standards of ethical conduct (\% indications)

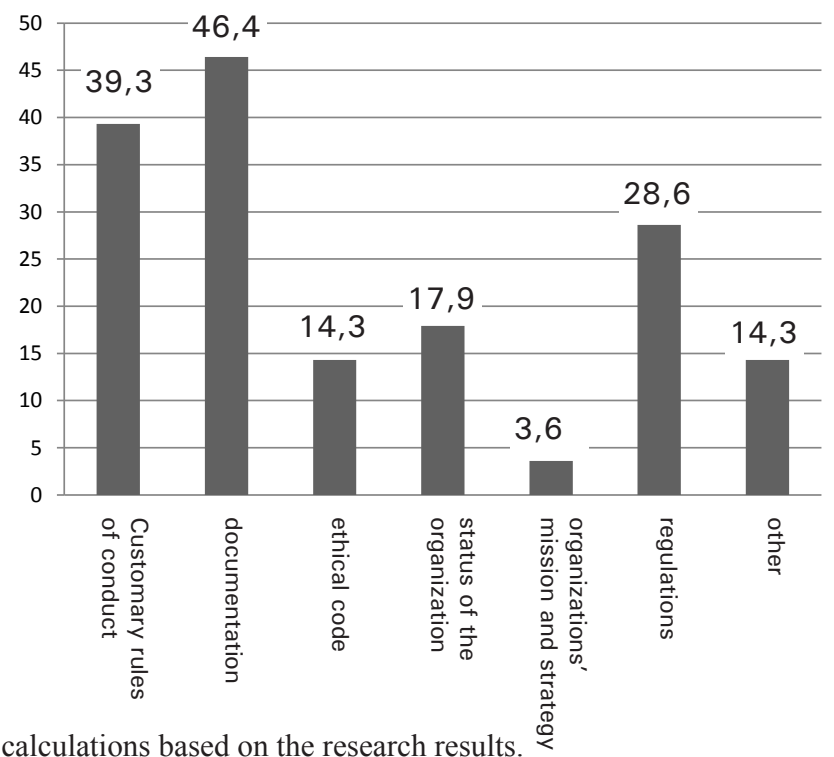

Source: own calculations based on the research results.

Also, it is vital that the respondents did not indicate only one form of the possessed standards. Some of them indicated regulations, statues, as well as their organizations' strategies.

The areas that in public organizations are considered as the ones that contribute to perceiving them as socially responsible entities include the following: reliable meeting of financial obligations, improving management systems in place, investing in expansion, paying attention to the creation of safe conditions, creating a friendly atmosphere in the workplace, giving support to employees that have been made redundant in gaining new professional skills, considering rights and interests of local communities, respecting environmental criteria, monitoring the influence on the environment, building corporate culture and image, respect- 
ing human rights, and reaching good financial results. In the respondents' opinions these actions should result in an improved image and reputation, increased identification of employees with the company, improved economic performance, better access to capital and media, enhanced influence on the development of society, legal regulations respected to a larger degree, greater interest of investors, and a greater chance to remain successful for a longer period of time in the realization of goals.

The above statements referred to the desired state. However, the respondents also indicated the obstacles hindering the implementation of social responsibility. In that respect the respondents were almost unanimous in their answers (over 90\% of indications were the same). The following were indicated as major obstacles:

- lack of initiative or support from authorities,

- lack of knowledge on CSR,

- poor organizational practices,

- lack of interest (expectations) on the part of society,

- lack of interest on the part of employees,

- lack of legal regulations,

- lack of standards,

- increased costs of activity.

The policies of the researched entities focused on customer service $(89.3 \%$ of indications) and respecting laws (85.7\%) (figure 3).

Figure 3. Major areas of the activity of the researched entities ( $\%$ of indications)

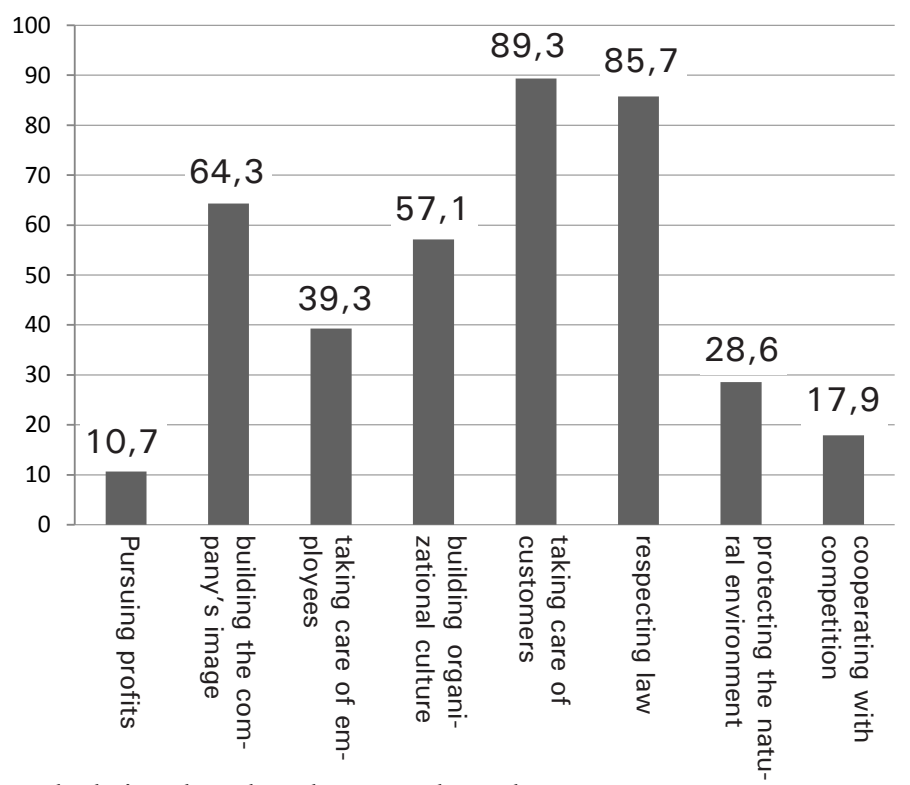

Source: own calculations based on the research results. 
These two answers include the concepts of the functioning of public organizations represented by the surveyed entities. On the one hand we can see a proclient approach that is typical of the concept of the New Public Management. One of the characteristics of the concept is addressing the organization's activities to recipients of public goods and services while in the 'old' public management activities are focused on clients and voters. On the other hand, following legal procedures is connected with a traditional approach to the public organization within which administering and concentrating on the bureaucratic activity play an important role.

Taking care of employees belongs to the activities encompassed by social responsibility. They are described, among other things, in the Global Compact Guide $^{3}$. This guide comprises ten rules and six of them concern the broadly understood employee rights and these are as follows:

- supporting and respecting human rights accepted by international society;

- eliminating cases of the violation of human rights by organizations;

- respecting the right to associate and conduct group negotiations;

- eliminating any form of compulsory work;

- abolishing work performed by children;

- eliminating discrimination in the sphere of employment.

In the researched entities it concerned the following areas:

- meeting the safety and hygiene regulations ( $78.6 \%$ of indications);

- taking care of social conditions $(60.7 \%)$;

- taking care of continual professional development and paying for it with the financial means of the organization $(57.1 \%)$;

- working out clear job descriptions (57.1\%);

- hiring employees for the positions that correspond to their professional qualifications (53.6\%);

- working out clear employee assessment criteria (53.6\%);

- respecting by the majority in the organization values and cultural norms $(50.0 \%)$;

- eliminating employee discrimination (46.4\%)

- providing extra rewards for creative and innovative employees $(35.7 \%)$;

- focusing on non-financial incentives $(32.1 \%)$;

- working out a clear motivational system (21.4\%);

- working out clear career paths (21.4\%);

- focusing on financial incentives (17.9);

- correlating rewarding employees with the workload and work quality $(17.9 \%)$;

- $\quad$ surveying needs and requirements concerning jobs (14.3\%);

${ }^{3}$ The complete version can be found in the following document: Global Compact Przewodnik, www.globalcompact.org.pl. 
- surveying the level of job satisfaction (14.3\%);

- undertaking activity for the benefit of employees' family members $(10.7 \%)$;

- giving preference to internal recruitment (3.6\%).

Less than a half of the researched entities organized training on the rules, behaviours, and values referring to social responsibility (figure 4). In $21.4 \%$ of the organizations such training was not held and in every fourth organization these issues were discussed but only partially. Employees from the surveyed entities participated in various training sessions concerning CSR mainly within the projects financed by the European Union.

Figure 4. Organization of training on social responsibility (\% of indications)

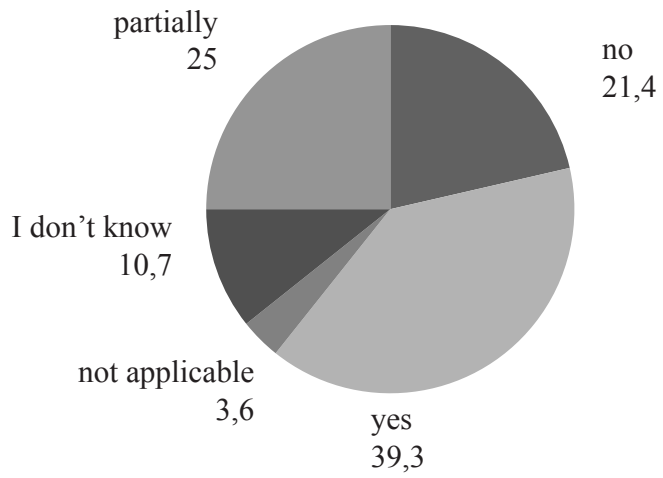

Source: own calculations based on the research results.

The most frequently selected forms of social responsibility in the examined entities included making equipment and facilities available $(67.9 \%$ of indications); giving financial (64.3\%) and material (50.0\%) support. Among the surveyed population only $3.6 \%$ were not able to provide any example of a socially responsible activity realized in their organizations. In more than $50.0 \%$ of the entities employees were encouraged to undertake some action that would benefit the local society. Yet another part of the organizations claimed that they had nothing to offer to local societies (14.3\%).

Another significant aspect in the implementation of the principles of social responsibility is its propagation. In recent years promoting CSR ideas has concentrated primarily on commercial entities, however, nowadays the understanding of the need for social responsibility concerns the public sector, too. In the opinion of the surveyed entities propagating socially responsible activity rests mainly on parents, schools, media, persons managing organizations, and local society. Representatives of public organizations indicate also the role of governmental and self-governmental administration in promoting social responsibility. 


\section{Conclousions}

Considering the functioning of the public organization in the context of CSR it may be stated that the majority of the assumptions that concern corporate social responsibility may be referred to the public sector. It is clearly seen in the light of the concept of the New Public management and the New Public Service. If in traditional public management, the external responsibility of employees, and of the organization itself as well, focuses on hierarchical activities, that means on the responsibility controlled by democratically elected politicians, then in new approaches it focuses on recipients of public goods and services. It becomes even more transparent in the concept of managing public organizations based on the theory of the New Public Service. This concept takes into account legal liability, national values, political norms, vocational standards and the interest of citizens.

It follows from the research conducted that public organizations are familiarised with the principles of social responsibility and in most cases possess approved standards to be respected. These standards are based on customary norms; however, their occurrence in the form of written codes and guidelines is becoming more frequent. Overall, we can formulate a statement that despite the fact that public organizations have to be socially responsible, they frequently do not fulfil the basic assumption of the presented model - they are not oriented towards citizens' needs.

\section{Literature}

Carrol A. B. (1994), Social issues in management research. Experts' Views, Analysis, and Commentary, "Business and Society", 33 (1).

Friedman M. (1997), Społeczna odpowiedzialność biznesujest pomnażanie zysku, Wydawnictwo W drodze, Poznań.

Global Compact Przewodnik. www.globalcompact.org.pl z 13.02.2011.

Griffin R.W. (2008), Podstawy zarzqdzania organizacjami, Państwowe Wydawnictwa Naukowe, Warszawa.

Kieżun W. (2005), Kapitat społeczny a sprawność sfery publicznej, [in:] Z teorii i praktyki zarzq̨dzania publicznego, Fundacja Współczesnego Zarządzania, Białystok.

Kotarbiński T. (1987), Opiekun spolegliwy. Pisma etyczne, Ossolineum, Wrocław.

Kożuch B. (2005), Specyficzne cechy organizacji publicznej, [in:] Z teorii i praktyki zarzqdzania publicznego, Fundacja Współczesnego Zarządzania, Białystok.

Kożuch B. (2004), Zarzadzanie publiczne. W teorii i praktyce polskich organizacji, Wydawnictwo Placet, Warszawa.

Zalewski A. (2006), Nowe zarzadzanie publiczne jako instrument poprawy efektywności sektora publicznego, [in:] Zarzqdzanie organizacjami publicznymi, K. Krukowski (ed.), Uniwersytet Warmińsko-Mazurski w Olsztynie, Olsztyn. 
